\title{
Impact of different omega-3 fatty acid sources on lipid, hormonal, blood glucose, weight gain and histopathological damages profile in PCOS rat model
}

\author{
Fiza Komal ${ }^{1}$, Muhammad Kamran Khan ${ }^{1}$, Muhammad Imran' ${ }^{1}$, Muhammad Haseeb Ahmad ${ }^{1}$, Haseeb Anwar ${ }^{2}$, \\ Usman Ali Ashfaq ${ }^{3}$, Nazir Ahmad ${ }^{1}$, Amna Masroor ${ }^{1}$, Rabia Shabir Ahmad ${ }^{1 *} \mathbb{D}$, Muhammad Nadeem \\ and Mahr Un Nisa ${ }^{1 *}$ (D)
}

\begin{abstract}
Background: Omega-3 fatty acids ( $\Omega$-3 PUFAs) may help to improve health status in polycystic ovarian syndrome (PCOS) by reducing numerous metabolic disorders (insulin sensitivity, hyperinsulinemia, lipid profile, obesity and inflammation). To evaluate the current objective, 16 weeks ( 6 weeks of adjustment period followed by 10 weeks of collection period) research trial was planned to check the impact of different sources of $\Omega$-3 PUFAs (synthetic $\Omega-3$, flaxseed and fish oil) on nutrient digestibility, weight gain, productive (lipid profile, glucose and insulin), reproductive profile (progesterone, follicle stimulating hormone (FSH), estrogen, luteinizing hormone (LH) and prolactin) and histological study of ovarian tissues in Wistar female rats.

Methods: Forty-five rats of $130 \pm 10 \mathrm{~g}$ weight were divided into 5 groups, each having 9 rats: NC (negative control without PCOS), PC (positive control with PCOS), SO (synthetic omega-3 containing ALA, EPA and DHA), FO (flaxseed oil) and F (fish oil) fed at $300 \mathrm{mg} / \mathrm{kg} /$ orally/daily of these sources were added in the basal diets while PC and NC received only the basal diet. Food and water were offered ad libitum. PCOS was induced in the rats fed of PC, SO, FO and $\mathrm{F}$ diets group by single intramuscular injection of estradiol-valerate ( $4 \mathrm{mg} / \mathrm{rat} / \mathrm{IM})$. Body weight and blood glucose was recorded weekly. At $16^{\text {th }}$ week of trial, blood samples were collected for lipid and hormonal analysis. Ovarian tissues were removed for pathological evaluation. Digestibility was measured by total collection method.

Results: Cholesterol, triglycerides and low-density lipoproteins were reduced in SO, FO and F groups when compared with rats of PC group. However, increasing trend of high-density lipoprotein (HDL) was found in same groups. The highest $\mathrm{HDL}(36.83 \pm 0.72 \mathrm{mg} / \mathrm{dL})$ was observed in rats fed $\mathrm{F}$ diet. In case of a hormonal profile, testosterone, $\mathrm{LH}$ and insulin levels showed a significant reduction after treatments. Blood glucose results showed significantly reducing trend in all the rats fed with $\Omega-3$ PUFAs sources than PC from 5 to 10 th week of trial. However, similar trend was noticed in rat's body weight at the end of 6th week. In ovarian morphology, different stages of follicles were observed in groups fed SO, FO and F diets. Nutrient digestibility in PCOS induced rats was remained non-significant.
\end{abstract}

\footnotetext{
*Correspondence: rabiaahmad@gcuf.edu.pk; linknisa@gcuf.edu.pk

${ }^{1}$ Institute of Home and Food Sciences, Faculty of Life Sciences,

Government College University, Faisalabad, Punjab, Pakistan

Full list of author information is available at the end of the article
}

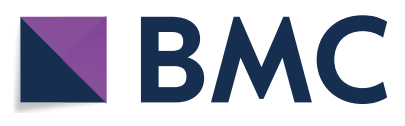

(C) The Author(s) 2020. This article is licensed under a Creative Commons Attribution 4.0 International License, which permits use, sharing, adaptation, distribution and reproduction in any medium or format, as long as you give appropriate credit to the original author(s) and the source, provide a link to the Creative Commons licence, and indicate if changes were made. The images or other third party material in this article are included in the article's Creative Commons licence, unless indicated otherwise in a credit line to the material. If material is not included in the article's Creative Commons licence and your intended use is not permitted by statutory regulation or exceeds the permitted use, you will need to obtain permission directly from the copyright holder. To view a copy of this licence, visit http://creativeco mmons.org/licenses/by/4.0/. The Creative Commons Public Domain Dedication waiver (http://creativecommons.org/publicdomain/ zero/1.0/) applies to the data made available in this article, unless otherwise stated in a credit line to the data. 
Conclusions: The three sources of $\Omega-3$ PUFAs had effective role in improving lipid and hormonal profile, reducing blood glucose, weight gain and histopathological damages in PCOS rats. However, fish oil source might be an innovative approach to cure PCOS via reducing the weight and metabolic anomalies due to EPA and DHA.

Keywords: PCOS, Infertility, $\Omega-3$ fatty acids, Flaxseed oil, Fish oil

\section{Background}

Polycystic ovarian syndrome (PCOS) is the endocrine disorder mainly occurs in $4-10 \%$ at reproductive age due to nutritional imbalance [1]. Imbalance in nutrient intake induces several metabolic diseases (dyslipidemia, insulin resistance and obesity) that will also lead to imbalance reproductive hormones (androgen, progesterone, estrogen, prolactin, FSH and $\mathrm{LH}$ ) and ultimately causes the PCOS [2]. In obese females, inflammation [3] and insulin resistance encourage the ovarian dysfunction for the androgen production [4]. In PCOS therapeutic management, medicine like metformin has been used conventionally. Dietary intervention for the reduction of obesity, dyslipidemia and hyperinsulinemia in PCOS patients is limited. That's why omega- 3 fatty acid ( $\Omega-3$ PUFAs) sources were selected as dietary intervention to synchronize the irregular metabolite in PCOS rats.

Several clinical and experimental researches showed that $\Omega$-3 PUFAs have been used for improving the lipid and insulin profile in obesity and inflammation [5-7]. However, responses of various food sources of $\Omega-3$ PUFAs are different due to variation in its chemistry configuration. Two food sources, flaxseed $\{\alpha$-linolenic acid (ALA) $\}$ and fish oil $\{($ eicosapentaenois acid (EPA), docosahexaenoic acid (DHA)\} contain chemically different $\Omega-3$ PUFAs. Very few researchers have observed that which important food sources with their $\Omega$-3 PUFAs profile had impact to reduce the metabolic disorder in induced PCOS rats. The goal of this study was to confirm the impact of dietary and synthetic sources of $\Omega-3$ PUFAs by which they can modify lipid and hormonal profiles, glucose level and body weight in PCOS induced rat model.

\section{Methods}

\section{Procurement of rats and their administration}

Forty-five days old, weighing $130 \pm 10$ g Wistar Albino female rats, which have 2 repeated estrus cycles had been bought from National Institute of Health (NIH), Islamabad, Pakistan. They were kept in a room under $12 \mathrm{~h}$ light/ dark cycle, at $25 \pm 1{ }^{\circ} \mathrm{C}$ temperature and relative humidity of 45 to $55 \%$. All experimental protocols for rats were carried out by adopting the procedures for the precaution and usage of laboratory animals accepted by the National Institutes of Health guide (NIH Publications
No. 8023, reviewed 1978). Animal Ethical Committee of Government College University, Faisalabad, Pakistan had proved this research by adopting Principles of Laboratory Animal Care. Completely Randomized Design was used by dividing rats into five groups each having 9 rats: NC (Negative control without PCOS), PC (Positive control with PCOS), SO (synthetic omega-3 containing ALA, EPA and DHA), FO (flaxseed oil) and F (fish oil) fed at $300 \mathrm{mg} / \mathrm{kg} /$ orally/daily of these sources were added in treatment groups by replacing that amount of fat content in basal diet, while PC and NC received only the basal diet (Table 1) [8]. Treatment groups were established by a balanced random allocation scheme. Isocaloric and isonitrogenous diet was prepared for all groups according to National Research Council (NRC) [9]. Animal feed and water was given ad libitum. The duration of in vivo trial was 16 weeks from which 6 weeks were adjustment period and 10 weeks were collection period. Food intake by the experimental rats was calculated weekly as the difference noted in the amount of food given, amount

\section{Table 1 Composition of experimental diet}

\begin{tabular}{|c|c|c|c|c|c|}
\hline $\begin{array}{l}\text { Ingredients (g/1000 g } \\
\text { diet) }\end{array}$ & NC & $\mathrm{PC}$ & so & FO & $\mathbf{F}$ \\
\hline Cornstarch & 347.49 & 347.49 & 347.49 & 347.49 & 347.49 \\
\hline Maltodextrin & 132 & 132 & 132 & 132 & 132 \\
\hline Sucrose & 100 & 100 & 100 & 100 & 100 \\
\hline Casein & 200 & 200 & 200 & 200 & 200 \\
\hline L-Cysteine & 3 & 3 & 3 & 3 & 3 \\
\hline Soyabean oil & 70 & 70 & 50.01 & 32.6 & 16 \\
\hline Cellulose & 100 & 100 & 100 & 100 & 100 \\
\hline AIN-93-VX vitamin mix & 10 & 10 & 10 & 10 & 10 \\
\hline AIN-93G-MX mineral mix & 35 & 35 & 35 & 35 & 35 \\
\hline $\mathrm{TBHQ}$ & 0.014 & 0.014 & 0.014 & 0.014 & 0.014 \\
\hline Choline bitartrate & 2.5 & 2.5 & 2.5 & 2.5 & 2.5 \\
\hline $\mathrm{SO}$ & 0 & 0 & 19.99 & 0 & 0 \\
\hline $\mathrm{FO}$ & 0 & 0 & 0 & 37.40 & 0 \\
\hline$F$ & 0 & 0 & 0 & 0 & 54 \\
\hline Total energy (kcal) ${ }^{\mathrm{a}}$ & 3660 & 3660 & 3660 & 3660 & 3660 \\
\hline
\end{tabular}

NC, Negative control; PC, Positive control; SO, (synthetic omega-3 containing $A L A, E P A$ and DHA); FO, (flaxseed oil); $F$, (fish oil) and TBHQ, tertiarybutylhydroquinone

a The estimate of caloric content was based on the standard physiological fuel values for $\mathrm{CHO}$, fat and

protein of 4, 9 and 4, respectively 
consumed and the amount remaining in each cage after 1 week of experimental period. PCOS were induced in all groups except $\mathrm{NC}$ by single intramuscular injection of estradiol-valerate ( $4 \mathrm{mg} / \mathrm{rat} / \mathrm{IM})$ dissolved in $0.2 \mathrm{~mL}$ oil during acclimatization period [10]. Subsequently, the PCOS induction was verified by visual method [11] and regular analysis of vaginal smear during anovulatory estrous cycle was performed during the examination of the study period [12]. Blood glucose and weight gain were recorded weekly.

\section{Fatty acids composition of oils by gas chromatography (GC)}

Preparation of reagents and methyl esters of fatty acids in the experimental oil samples under study were performed according to the method described by Asghar and Majeed [13] with some modifications. $2 \mathrm{~mL}$ of methanolic $\mathrm{H}_{2} \mathrm{SO}_{4}$ was mixed with $0.2 \mathrm{~mL}$ oil in a $50 \mathrm{~mL}$ screw capped Pyrex glass tubes. These glass tubes were put in a pre-heated oven at $80{ }^{\circ} \mathrm{C}$. The time was fixed for $1 \mathrm{~h}$ and frequent shaking of the tubes was carried out after $15 \mathrm{~min}$. Then, these glass tubes were taken out, cooled to room temperature and $2 \mathrm{~mL}$ of distilled water were added in each tube to stop the esterification reaction. After the completion of esterification process, the fatty acids esters were extracted using the petroleum ether $(1 \mathrm{~mL})$. This process was repeated thrice. After that, the ether content was evaporated under inert gas in heating block and remaining darkish oily upper surface $(1 \mu \mathrm{L})$ was injected into gas chromatograph (Agilent Technologies Inc. USA) equipped with flame ionization detector (FID) and column to obtain fatty acid methyl ester peaks. The column temperature was set at $150{ }^{\circ} \mathrm{C}$ and detector temperature was standardized at $250{ }^{\circ} \mathrm{C}$. The temperature was increased at the rate of $10{ }^{\circ} \mathrm{C} /$ minute to $250{ }^{\circ} \mathrm{C}$ and held there exact for $5 \mathrm{~min}$. The total experimental run time was noted 45-50 min for each sample. The individual peaks for all fatty acid methyl esters were identified. The obtained retention times of experimental peaks were compared with standard peaks. The fatty acid composition against each peak was calculated using the peak areas of the fatty acid species that appear in the chromatogram.

\section{Lipid profile analysis}

Lipid profile was checked by micro plate reader URIT 660 (URIT Medical Electronic Co., Ltd, Guangxi, China). Cholesterol was determined with kit method using Biosystems cholesterol kit REF. 11,505 (Barcelona, Spain) having limit of detection $4.2 \mathrm{mg} / \mathrm{dL}(0.10 \mathrm{mmol} / \mathrm{L})$ and linearity limit (1000 mg/dL; $26 \mathrm{mmol})$ with inter- and intra-assay CV $1.1 \%$. Triglyceride was estimated by Triglycerides kit (BioSystems S.A., Barcelona, Spain). The detection limit was $4.4 \mathrm{mg} / \mathrm{dL}(0.05 \mathrm{mmol} / \mathrm{L})$ and linearity limit $(600 \mathrm{mg} / \mathrm{dL} ; 6.78 \mathrm{mmol})$ while inter- and intra-assay CV was $2.8 \%$. LDL was determined through Wiener kit REF. 1,220,229 (Rosario, Argentina) having $\mathrm{CV}$ in the range of $2.6 \%$. The detection limit was $0.4 \mathrm{mg} /$ $\mathrm{dL}(0.01 \mathrm{mmol} / \mathrm{L})$ while linearity limit was detected $1000 \mathrm{mg} / \mathrm{dL}$ (26 mmol). HDL was determined through Wiener kit REF 1,220,114 (Rosario, Argentina) with CV in the range of $3.8 \%$. The detection limit was $0.5 \mathrm{mg} / \mathrm{dL}$ $(0.01 \mathrm{mmol} / \mathrm{L})$ while linearity limit was noted $200 \mathrm{mg} / \mathrm{dL}$ $(5.18 \mathrm{mmol})$ [14].

\section{Hormonal profile analysis}

Testosterone, progesterone, estrogen, follicle stimulating hormone (FSH), prolactin and luteinizing hormone (LH) were estimated through Enzyme Linked Immunosorbent Assay (ELISA) kits method (Biocheck, Inc. Foster City, CA 94,404, USA). Insulin was analyzed via ELISA kit method (Monobind Inc. Lake Forest CA 92630 USA).

\section{Blood glucose}

Weekly Blood glucose was checked by using the AccuChek $^{\circledR}$ Active glucometer (Roche Diagnostics $\mathrm{GmbH}$, Germany).

\section{Body weight}

Body weight of all rats were measured weekly by weighing balance.

\section{Histological study of ovarian tissues}

The ovarian tissues were put in buffer formalin (10\% solution) and fixed firmly in paraffin wax. 5-micron thick part (slice) was taken and staining was performed using eosin and haematoxylins solution. The cross sections (total 100 in number) per specimen were checked by using light microscope (Olympus, 3H-Z-Japan) to diagnose hyperaemia [10].

\section{Blood sampling}

At the last day of the study, $5 \mathrm{~mL}$ blood samples of rats were obtained for analyzing the serum lipid, insulin and reproductive hormone profile. Ovarian tissues were removed for pathological evaluation [10].

\section{Nutrient digestibility}

The nutrient digestibility assay was determined using quantities of nutrient intake and total produced excreta. Nutrients intake was recorded weekly until the end of trial while last ten days were kept for feces collection. The collected excreta (500 g) were homogenized for posterior removal and were placed in a forced ventilation oven at calibrated temperature $\left(60{ }^{\circ} \mathrm{C}\right)$ for calculated time $(72 \mathrm{~h})$ to get air-dried samples. Then, air-dried samples were 
grinded and weighed. Subsequently, the nutrient composition, dry matter, crude protein and gross energy profile of air-dried and experimental diets samples was determined to calculate the nutrient digestibility [15]. Based on the results of these parameters, the nutrient digestibility of the diets was calculated using the following expression.
HDL in rats was increased 33.02, 29.37 and 23.81\%, respectively in the rats of $\mathrm{F}, \mathrm{SO}$ and $\mathrm{FO}$ groups when compared it with rats fed PC diet. However, cholesterol, triglycerides and LDL were significantly reduced in rats fed F, SO and FO diet as compared to rats fed PC diet. Highest reduction in serum cholesterol, triglycerides and LDL were observed in rats fed F diet that is about

$$
\text { Nutrient Digestibility }(\%)=\frac{\text { Nutrient intake }- \text { Nutrient in feces } \times 100}{\text { Nutrient intake }}
$$

\section{Statistical analysis}

Completely Randomized Design was used by making 5 experimental units, each treatment comprising of 9 rats. All the data collected were statistically measured for mean and standard error. Statistical analysis was carried out by one-way ANOVA using SPSS Statistics for Windows, version 17 (SPSS Inc., Chicago, Illinois., USA). Comparison of means for omega fatty acids doses on weekly blood glucose and body weight change was observed via Duncan Multiple Range Test [16]. The difference in the mean values of the two groups was considered statically significant if the "P" value was equal to or less than 0.05 and non-significant (N.S.) if the "P" value was greater than 0.05 .

\section{Results}

\section{Lipid profile}

The fatty acids composition of oils present in different experimental diets has been described comprehensively in Table 2. There was significant difference in lipid profile of rats in different groups, data is shown in Fig. 1.
$16.28,15.80$ and $14 \%$, respectively, when compared it with rats fed PC diet. However, overall trend in serum lipid profile was remained non-significant among rats fed $\mathrm{SO}, \mathrm{FO}$ and $\mathrm{F}$ diets and become in normal range as shown in rats fed NC diet.

\section{Hormonal profile}

The results regarding hormonal profile among rats fed NC, PC, SO, FO and F diets have been shown in Fig. 2. Results showed that after the supplementation of different sources of $\Omega-3$ fatty acids, the levels of testosterone, LH and insulin were significantly reduced in rats fed SO, FS and F diets. However, all treatments were nonsignificant to each other and were significant from the PC. Serum progesterone, LH, prolactin and estrogen level in rats fed SO, FO, F and PC diets showed nonsignificant results.

\section{Blood glucose}

At the end of $4^{\text {th }}$ week, $\mathrm{SO}, \mathrm{FO}$ and $\mathrm{F}$ diets did not show any significant effect in rats blood glucose (Table 3). From

Table 2 Fatty acids composition of oils present in different experimental diets

\begin{tabular}{lllll}
\hline Fatty acids $\mathbf{g} / \mathbf{1 0 0} \mathbf{g}$ & Soybean oil & Flaxseed oil (ALA) & Fish oil (EPA+ DHA) & $\begin{array}{l}\text { Synthetic } n \text {-3 PUFAs } \\
\text { (ALA + EPA + DHA) }\end{array}$ \\
\hline Polyunsaturated fatty acids & 57.9 & $70.35 \mathrm{~g}$ & $22.5 \mathrm{~g}$ & $100 \mathrm{~g}$ \\
Linoleic acid $(18,2, \mathrm{n}-6)$ & 54.2 & 17.04 & 0.935 & 0 \\
Linolenic acid $(18: 3, \mathrm{n}-3)$ & 7.7 & 53.31 & 0.935 & 33.33 \\
EPA (20:5, $\mathrm{n}-3)$ & 0.1 & 0 & 6.9 & 33.33 \\
DHA (22:6, $\mathrm{n}-3)$ & 0.1 & 0 & 11.97 & 33.33 \\
Others & - & 0 & 1.76 & - \\
Monounsaturated fatty acids & 22.78 & $20.19 \mathrm{~g}$ & $46.7 \mathrm{~g}$ & 0 \\
Oleic acid (18:1) & 20.4 & 20.19 & 2.81 & 0 \\
Others & 2.38 & 0 & 43.89 & - \\
Saturated fatty acids & 15.65 & $9.46 \mathrm{~g}$ & $30.8 \mathrm{~g}$ & 0 \\
Myristic acid (14:0) & 0.1 & 0.06 & 5.07 & 0 \\
Palmitic acid (16:0) & 9.7 & 5.30 & 18.6 & 0 \\
Stearic acid (18:0) & 3.6 & 4.10 & 2.7 & 0 \\
Others & - & 0 & 4.43 &
\end{tabular}




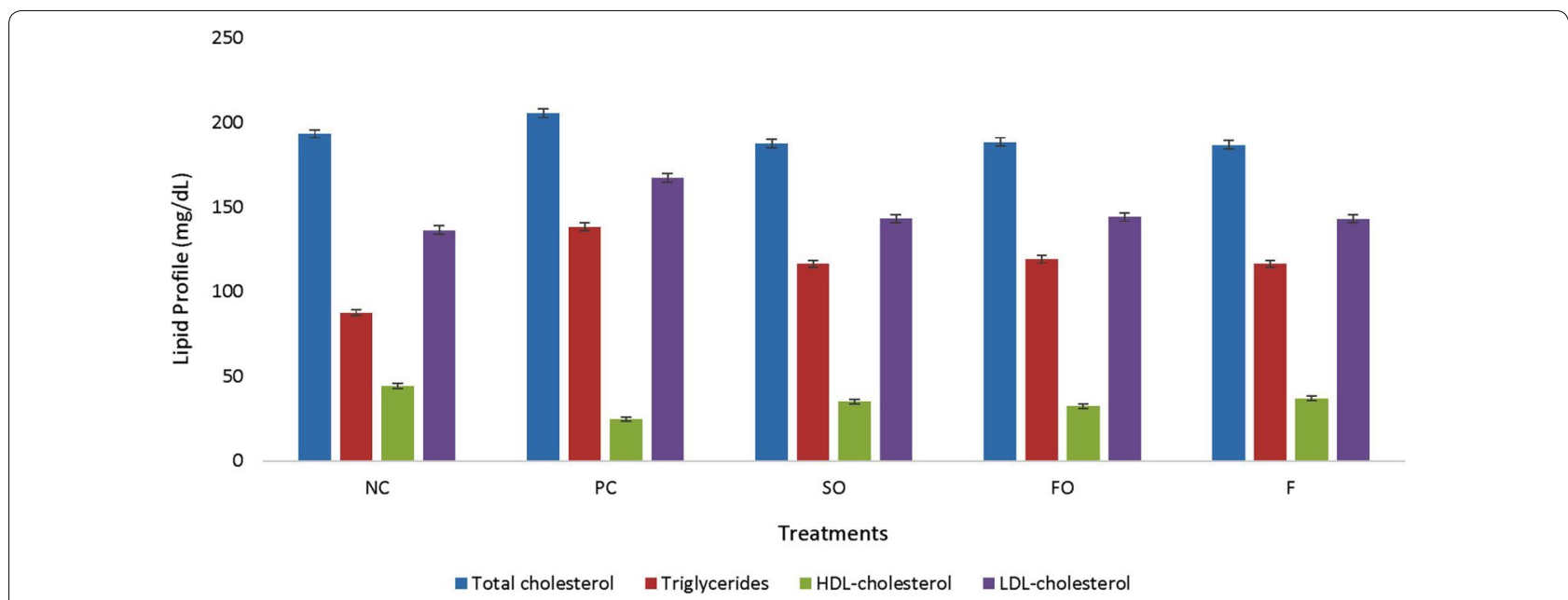

Fig. 1 Effect of different sources of $\Omega-3$ fatty acids on lipid profile in PCOS induced rats (negative control, NC; positive control, PC; synthetic $\Omega$-3, SO 300 mg/kg/orally/daily; flaxseed oil, FO 300 mg/kg/orally/daily; fish oil, F 300 mg/kg/orally/daily; HDL, high density lipoprotein and LDL, low density lipoprotein)

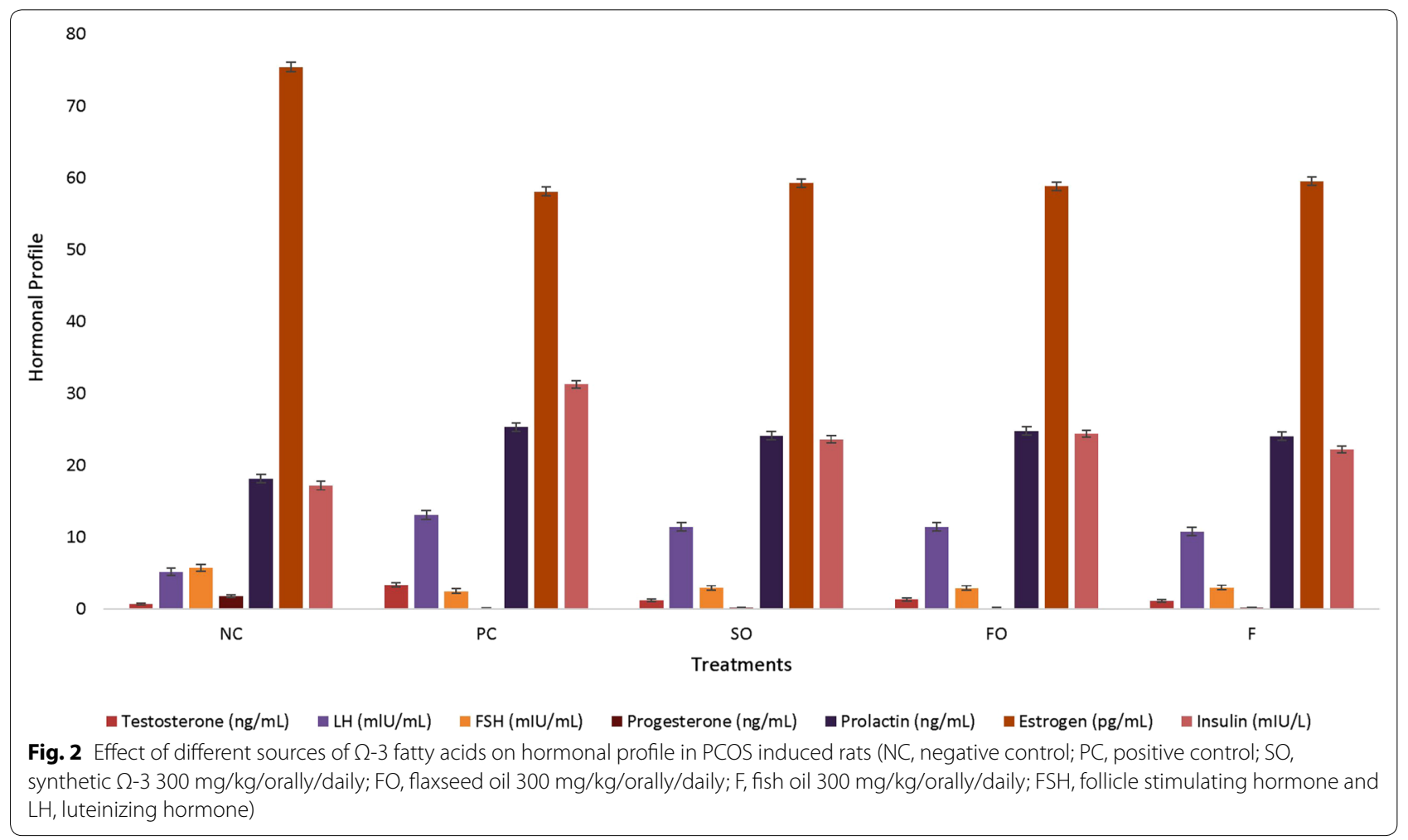

5 to 10th weeks SO, FO and F diet had positive effect on decreasing rat's blood glucose that is about $17.03 \%$ reduction in last week when compared it with rats fed PC diet. However, this decreasing trend in rat's blood glucose in $\mathrm{SO}, \mathrm{FO}$ and $\mathrm{F}$ group was remained non-significant to each other.

\section{Body weight}

At the end of 6th week, there was significant reduction in body weight of rats fed SO, FO and F diet as compare to rat's body weight fed PC diet (Fig. 3). However, in the initial five weeks, all diets showed same trend in body weight of rats fed SO, FO, F and PC diets. At the end of trail, there was $11.07 \mathrm{~g}$ reduction of body weight observed in rats fed F diet than rats fed PC diet that is 
Table 3 Effect of different sources of $\Omega-3$ fatty acids on weekly blood glucose $(\mathrm{mg} / \mathrm{dL})$ in PCOS induced rats

\begin{tabular}{llllll}
\hline Weeks & Treatments & & & \\
\cline { 2 - 5 } NC & PC & SO & FO & F & \\
\hline 1st & $97.03 \pm 0.73 a$ & $164.27 \pm 0.64 b$ & $162.70 \pm 0.90 b$ & $163.10 \pm 0.81 b$ & $162.27 \pm 0.92 b$ \\
2nd & $99.17 \pm 0.60 \mathrm{a}$ & $163.94 \pm 0.91 \mathrm{~b}$ & $162.50 \pm 0.98 \mathrm{~b}$ & $162.82 \pm 0.98 \mathrm{~b}$ & $162.36 \pm 0.95 \mathrm{~b}$ \\
3rd & $95.03 \pm 0.88 \mathrm{a}$ & $157.00 \pm 0.57 \mathrm{~b}$ & $155.80 \pm 0.64 \mathrm{~b}$ & $156.00 \pm 0.66 \mathrm{~b}$ & $155.13 \pm 0.62 \mathrm{~b}$ \\
4th & $91.82 \pm 0.99 \mathrm{a}$ & $160.73 \pm 0.94 \mathrm{~b}$ & $158.23 \pm 0.95 \mathrm{~b}$ & $158.70 \pm 0.96 \mathrm{~b}$ & $157.73 \pm 0.84 \mathrm{~b}$ \\
5th & $93.88 \pm 0.92 \mathrm{a}$ & $157.85 \pm 0.64 \mathrm{c}$ & $150.36 \pm 0.73 \mathrm{~b}$ & $150.63 \pm 0.79 \mathrm{~b}$ & $149.40 \pm 0.97 \mathrm{~b}$ \\
6th & $85.06 \pm 1.05 \mathrm{a}$ & $159.32 \pm 1.27 \mathrm{c}$ & $145.46 \pm 0.78 \mathrm{~b}$ & $146.00 \pm 0.58 \mathrm{~b}$ & $145.77 \pm 0.98 \mathrm{~b}$ \\
7 th & $96.79 \pm 0.67 \mathrm{a}$ & $162.39 \pm 0.39 \mathrm{c}$ & $149.10 \pm 0.81 \mathrm{~b}$ & $149.77 \pm 0.27 \mathrm{~b}$ & $148.80 \pm 1.11 \mathrm{~b}$ \\
8th & $92.83 \pm 0.85 \mathrm{a}$ & $163.47 \pm 0.48 \mathrm{c}$ & $140.87 \pm 0.61 \mathrm{~b}$ & $141.10 \pm 1.07 \mathrm{~b}$ & $140.47 \pm 0.79 \mathrm{~b}$ \\
9th & $98.53 \pm 0.74 \mathrm{a}$ & $167.03 \pm 0.73 \mathrm{c}$ & $136.80 \pm 0.36 \mathrm{~b}$ & $137.20 \pm 0.89 \mathrm{~b}$ & $136.63 \pm 1.22 \mathrm{~b}$ \\
10 th & $99.26 \pm 0.77 \mathrm{a}$ & $165.84 \pm 0.74 \mathrm{c}$ & $137.50 \pm 0.78 \mathrm{~b}$ & $139.77 \pm 0.12 \mathrm{~b}$ & $137.60 \pm 0.30 \mathrm{~b}$ \\
\hline
\end{tabular}

PCOS, Polycystic Ovarian Syndrome

Negative control (NC); Positive control (PC); Synthetic $\Omega-3$ (SO $300 \mathrm{mg} / \mathrm{kg}$ ); Flaxseed oil (FO

$300 \mathrm{mg} / \mathrm{kg}$ ); Fish oil (F $300 \mathrm{mg} / \mathrm{kg}$ )

Within a row means denoted by a different letter are statistically significant $(p<0.05)$

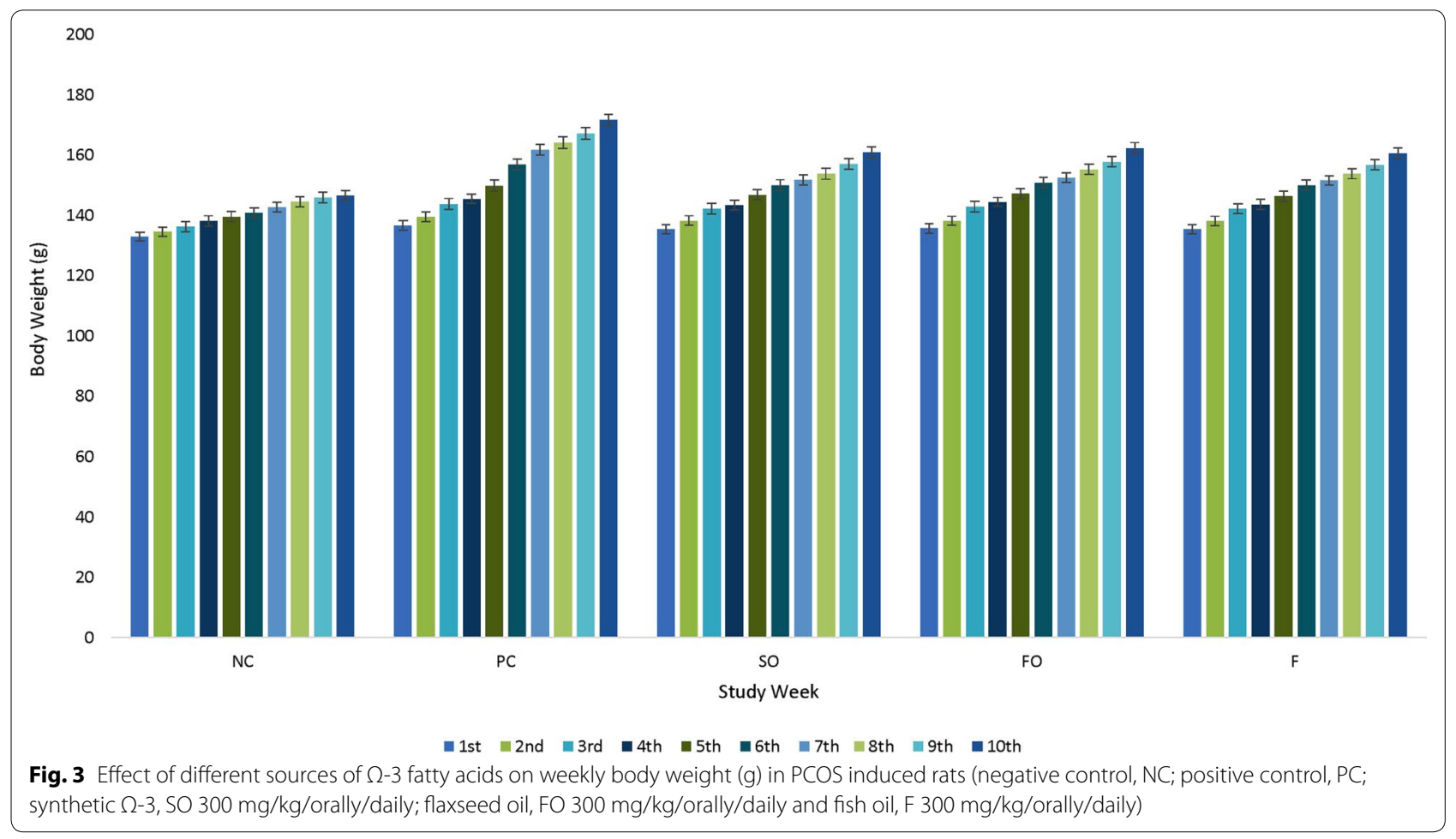

about $6 \%$. Figure 3 shows that body weight of rats was controlled in group SO, FO and F groups as compared to $\mathrm{PC}$ that was increasing with age.

\section{Pathological evaluation of ovaries}

Sections of ovaries from control group animals showed healthy structures of follicles in different development stages with aggregation of granulose cell (GC) and the corpus luteum (CL) (which is a definite sign of ovulation) were observed (Fig. 4a). A large number of cystic follicles (CF) with thin layer of granulose cells (GC) were observed in PCOS induced rats. Corpora lutea were completely absent indicating anovulation (Fig. 4b). After supplementation of different sources of 


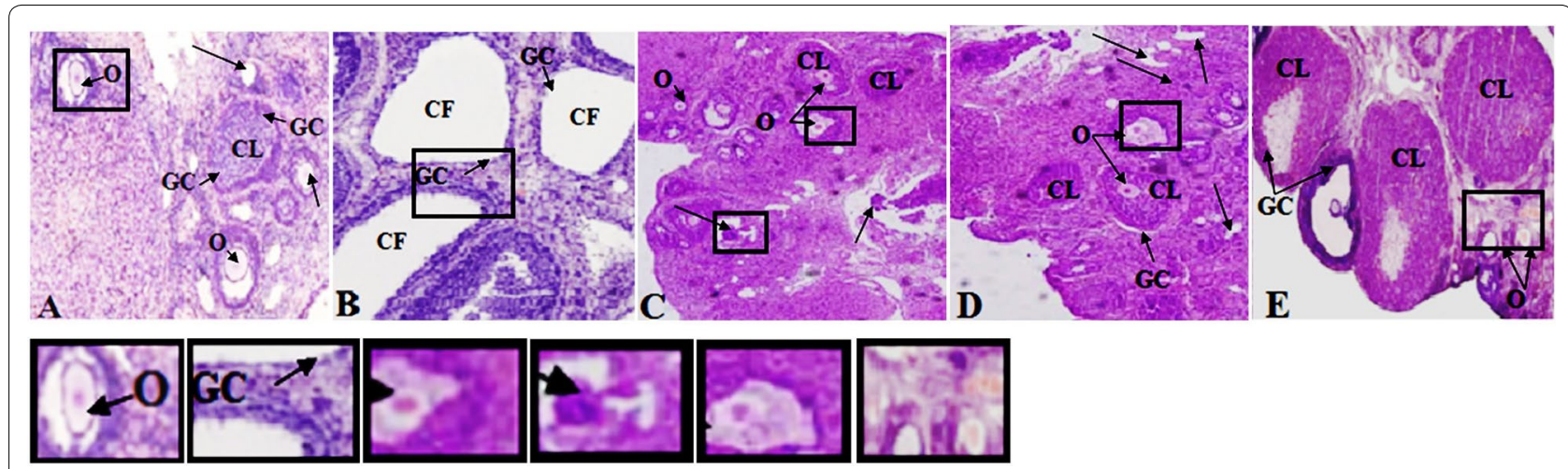

Fig. 4 Ovarian histopathological examination of PCOS induced rats. Histological sections were stained with hematoxylin and eosin. In negative control group (a H\&E $\times 100$ ), various stages of follicles were developed normally with aggregation of granulosa cells. In positive control group (b $\mathrm{H} \& \mathrm{E} \times 100$ ), many follicular cysts were present in PCOS rats ovaries with degrading and thin layer of granulosa cells. After treatment of different sources of omega-3 fatty acids, few follicles with different developmental stages were observed in groups treated with SO, FO and F diets (c, d, e: H\&E × 100). CF: (Cystic follicles), CL: (Corpus luteum), GC: (Granulosa cells), O: (Corpus Luteum).

S-3 fatty acids, no ovarian cysts were seen and normal sized healthy follicles at different developmental stages with oocytes, corpus luteum $(\mathrm{CL})$ and clear, visible granulosa cell (GC) layer were observed in rats fed SO, FO and F diets (Fig. 4c-e).

\section{Nutrient digestibility}

The results showed that the effect of different sources of $\Omega-3$ fatty acids on nutrient digestibility in PCOS induced rats was remained non-significant. The digestibility of dry matter (DM), crude protein (CP), ether extract (EE) and crude fiber (CF) was not change statistically in all rats fed diets containing $\Omega-3$ fatty acids sources compared with $\mathrm{NC}$ and $\mathrm{PC}$. The results of nutrient digestibility of rats fed $\mathrm{NC}, \mathrm{PC}, \mathrm{SO}, \mathrm{FO}$ and F diets are given in Table 4.

\section{Discussion}

The current study confirmed that supplementation of $\Omega-3$ PUFAs sources had healthy impacts on lipid profile, blood glucose and body weight of PCOS rats when compared it with rats fed PC diet. Numerous studies have found that feeding fish oil (FO) and flaxseed oil (FSO) helps to decrease cholesterol, triglycerides (TG) and LDL while increases the level of HDL in animal/human [17-20]. These food sources having $\Omega-3$ PUFAs with different configuration named EPA, DHA and ALA play a key role for reducing the plasma TG, LDL and cholesterol by activating the transcription factors which control and regulate the nutrient traffic of lipid metabolism pathways in a tissue by enhancement of $5^{\prime} \mathrm{AMP}$-activated protein kinase (AMPK). The AMPK have been characterized as a major sensor of cellular energy status which furthermore regulates the partitioning process between lipid oxidation and lipogenesis [21, 22]. Various mechanisms have been prescribed in the literature to explain the effects of $\Omega-3$ PUFAs on serum lipids. $\Omega-3$ PUFAs slow down hepatic production of fatty acids in the biological system.

Table 4 Effect of different sources of $\Omega-3$ fatty acids on nutrient digestibility in PCOS induced rats

\begin{tabular}{llllll}
\hline Parameters \% & \multicolumn{3}{l}{ Treatments } & & \\
\hline & NC & PC & SO & FO & F \\
DM & $75.40 \pm 1.16$ & $74.46 \pm 0.81$ & $75.27 \pm 1.05$ & $74.23 \pm 1.31$ & $74.98 \pm 1.45$ \\
CP & $74.26 \pm 1.08$ & $74.06 \pm 1.00$ & $73.56 \pm 1.25$ & $73.94 \pm 1.39$ & $74.34 \pm 1.09$ \\
EE & $86.54 \pm 1.47$ & $85.68 \pm 1.25$ & $85.13 \pm 1.17$ & $84.34 \pm 1.16$ & $84.23 \pm 1.17$ \\
CF & $36.42 \pm 1.23$ & $37.63 \pm 1.16$ & $38.12 \pm 1.18$ & $38.78 \pm 1.32$ & $38.12 \pm 1.11$ \\
\hline
\end{tabular}

Negative control (NC); Positive control (PC); Synthetic $\Omega-3$ (SO $300 \mathrm{mg} / \mathrm{kg}$ ); Flaxseed oil (FO

$300 \mathrm{mg} / \mathrm{kg}$ ); Fish oil (F $300 \mathrm{mg} / \mathrm{kg}$ ); Dry matter (DM); Crude protein (CP); Ether extract (EE) and Crude fiber (CF)

$\mathrm{DM}$, Dry matter; $\mathrm{CP}$, Crude protein; $\mathrm{EE}$, Ether extract and CF, Crude fiber 
The process mechanism may involve suppressing of gene expression of sterol regulatory element-binding proteins. As a result, the gene expression of enzymes is depressed which are involved in synthesis of fatty acids (fatty acid synthetase complex and acetyl-coenzyme A carboxylase) [20]. In the modulation of levels of triglycerides, $\Omega-3$ PUFAs also influence additional nuclear receptors that are concerned with these e.g., farnesol $\mathrm{X}$ receptor, liver $\mathrm{X}$ receptor and hepatocyte atomic factor $4 \alpha$. Furthermore, lipoprotein lipase is helpful for disposal of triglycerides from circling chylomicron particles [23]. However, some studies showed that EPA and DHA perform better as compare to ALA for altering the lipid profile because some people could not convert ALA in to active form for their proper functioning and utilization in the body [24].

The present research work has demonstrated that $\mathrm{SO}$, $\mathrm{FO}$ and $\mathrm{F}$ had significant effect in reducing testosterone, $\mathrm{LH}$ and insulin while $\mathrm{FSH}$, progesterone, prolactin and estrogen remained non-significant. The outcomes of recent research work are in line with the results of Azadeh et al. [25] who showed that after 8 weeks of the trial, the supplementation of $\Omega$-3 PUFAs decrease the testosterone concentration. This decrease might be due to the effect of $\Omega-3$ on LH. Hyperandrogenism has been observed as first clinical symptom in the patients with irregularity in steroid production. Generally, the increase in estrogen secretion leads to production of this condition. Furthermore, the LH hypersecretion is the major reason for increase in serum levels 17 hydroxyprogesterone and testosterone [26]. According to Phelan et al. [27], PUFAs supplementation leads to significant reduction in testosterone production level. It is also evident from the results that the concentrations of reproductive hormones like estrogen, LH, or FSH were not changed significantly. The previous studies reported that flaxseed consumption and/or supplementation in the experimental diets is effective in reducing the LH levels [28, 29]. LH has key role in androgen production and theca cells are responsible to produce the androgens in abundant concentration. Moreover, LH increases the production level of androgen hormones such as testosterone from the adrenal gland and ovary in PCOS which causes the infertility in the subject. The aromatization of these androgens to oestradiol is done by the FSH in granulosa cells and these conditions produce high number of immature follicles which is further enhanced by irregular production of androgen in PCOS. In this context, the omega- 3 fatty acids help to decrease serum androgen levels [30].

Azadeh et al. [25] confirmed that after the addition of $\Omega-3$, prolactin, progesterone and estrogen concentrations did not significantly change. In this case, no similar study of changes in prolactin has been found. The mean change in prolactin was non-significant after eight weeks of research. Women with PCOS are at risk of metabolic disorders including inflammation, hyperinsulinemia and oxidative stress [31]. There were only a few researches to estimate the effects of $\Omega-3$ PUFAs in PCOS women on insulin. Mohammadi et al. [32] which confirmed that taking $\Omega$-3 PUFAs from fish oil for eight weeks at a dose of $4 \mathrm{~g} /$ day had a positive effect on the level of serum insulin and glucose uptake in PCOS patients. EPA and DHA containing $\Omega-3$ PUFAs have anti-obesity, anti-insulin resistance and anti-inflammatory functions [33] by enhance insulin sensitivity due to declining inflammatory cytokines including tumor necrosis factor, interlukin-6 and enhancing emission of anti-inflammatory adiponectin [34]. However, studies with comprehensive experimental time duration are suggested in order to get more effective results.

Blood glucose level was reduced (17-17.03\%) in PCOS rats fed different sources of $\Omega-3$ PUFAs at the end of $10^{\text {th }}$ week of trial when compared it with rats fed PC diet. Sahar [35] had also found similar result that there was $49.09 \%, 44.0 \%$ and $44.9 \%$ reduction in blood glucose level after offering supplementation of fish oil, flaxseed oil and fish oil + flaxseed oil, respectively at $8^{\text {th }}$ week of trial. The findings of different scientists who studied that supplementation of different sources of $\Omega$-3 PUFAs have beneficial effects on glucose [36-39]. The $\Omega-3$ PUFAs might be the important source for the reduction of blood glucose level by raising the sensitivity of insulin signal that attributed by receptor of G-protein for the production of glucagon-like peptide 1 (GLP-1) from enteroendocrine cells, up-regulation of the apelin pathway, and down-regulation of other control pathways for insulin production [40, 41]. In current study, the reduction in blood glucose noticed in PCOS rats fed different sources of $\Omega-3$ PUFAs might be due to presence of EPA form that is important substrate for the formation of G-protein-coupled receptors [42]. It has also been observed that omega-3 fatty acids also enhance the function of adiponectin hormone which is responsible to play role for reduction in fasting glucose. Adiponectin hormone reduces hepatic glucose output and lead towards increased peripheral insulin sensitivity through promotion of lipid oxidation process [43]. The reduction in blood glucose level might also be due to mechanisms based on substituting of fuel with increased glucose utilization and reduced fatty acid accessibility and enhancing the effect of insulin, the cycle involved with glucose-fatty acids could also be the reason [44].

The supplementation of $\Omega-3$ PUFAs significantly decrease the body weight of PCOS rats fed SO, FO and F diets when compared it with rats fed PC diet. However, response of reduction in body weight was the same in rats fed different sources $\Omega-3$ PUFAs. Vaughan et al. [45] had also found decrease in body weight of the PCOS 
subjects offering different sources of $\Omega-3$ PUFAs in diets by improving metabolism and fat burning potential by the improvement of GLP-1 which is the "satiety" hormone, well recognized to do a major function in brain to comeback declining hunger and so energy intake [46, 47]. $\Omega-3$ PUFAs fed by subjects also effect on leptin that reduce the appetite and effect on the production of the obese gene non-glycosylated protein, well known for its effect on dropping the body weight [48]. Bathena et al. [49] also proved that flaxseed had potential advantages of diminishing the fat preservation in the liver of hereditarily obese animals that ultimately might have effect on reducing body weight.

In this present study, $\Omega-3$ PUFAs treatment advanced to disappearance of cysts. Higher concentrations of corpora lutea have been noticed which suggests that ovulation and estrous cyclicity was normal. Visible granulosa cell layer surrounded the oocytes which were developed within the ovary follicles at different development stages. Ovarian cortex appearance was also normal. Only a few corpus luteum and a large number of follicular cysts were seen in PCOS induced rats. The form of corpora lutea is considered as occurrence of ovulation. Earlier published studies have extensively described the numerous mechanisms for the impacts of $\Omega$-3 PUFAs on ovaries and follicle structures. $\Omega$-3 PUFAs have been observed as a stimulator of FSH which cause follicular growth, ability and development of follicular rupture and ovuation [50]. EPA and DHA are the two unique biological signaling factors that cause ovulation and enhance the flow of blood to the ovaries to promote follicles growth and increase ovarian weight [51]. The intake of $\Omega$-3 PUFAs promotes the release of gonadotropin-releasing hormone $(\mathrm{GnRH})$ primarily regulated by hypothalamic receptors of the reproductive system, which subsequently mediate the release of LH and FSH from pituitary glands [52]. A high intake of fish oil leads to a considerable rise in follicles development and ovulation and these actions depend on the hypothalamic-pituitary function [53]. $\Omega-3$ PUFAs stimulated the follicogenesis process in ovaries, which may positively affect the efficiency of fertility [54]. The current study's results were similar to the results of Manneras et al. [55] who exposed that the PCOS rat model induced by estradiol valerate had asymmetrical cycles. Their ovaries had huge, atretic antral follicles, follicular cysts with a thickened theca internal cell layer, and a small number of fresh corpora lutea, related to our current consequences. In this current study, the $\Omega-3$ PUFAs supplementation significantly improved the corpora lutea concentration. Moreover, the corpora lutea level in relation to total follicle strength and antral follicle numbers was found higher which were noticed in line to Manni's research [56]. The achievable clarification for the development of cyclicity is that reduced sympathetic activity which has a straight effect on the ovaries. This process also greatly affects the sex steroid synthesis pathways. It has been documented in research studies that physical exercise could lead towards reduced sympathetic nerve activity, regular menstrual frequency and lowers the sex steroid level in PCOS women [57]. Furthermore, the significant increase in granular layer thickness and corpora lutea area was seen in experimental groups treated with abundant $\Omega-3$ PUFAs. The ratio of numbers of corpora lutea to total numbers of follicle was higher in treated groups. Lifestyle interference of human PCOS has been extensively accepted. Our experimental outcomes were also in agreement with the findings of Elaheh et al. [58] who observed that $\Omega$-3 FAs could helpful to recover hyperemia and diminish hemorrhage in experimental PCO groups. Moreover, $\Omega-3$ PUFAs play role to protect cells during injury and unfavorable conditions [59].

The digestibility of DM, CP, EE and CF was not change statistically in all rats fed diets containing $\Omega-3$ PUFAs sources compared with $\mathrm{NC}$ and PC. No comprehensive work has been done regarding the direct effect of $\Omega-3$ PUFAs on nutrient digestibility in PCOS rats. Digestibility results of the present study are in agreement with that of Smink et al. [60] who reported that omega fats have higher absorption efficiencies and consequently digestibility coefficients when compared with saturated fats. This is may be due to the fact that monounsaturated and polyunsaturated fats have the ability to form proper micelles which enhance the digestibility process, whereas saturated fats may have an irregular micelles formation because of their characteristic low polarity [61]. This characteristic of saturated fats would increase the viscosity of digesta in the gastrointestinal tract and subsequently decrease the digestion and absorption of saturated fats.

\section{Conclusions}

This research work significantly contributed to the knowledge of $\Omega-3$ PUFAs in PCOS by having positive impact in improving the productive and reproductive hormones, blood glucose, lipid profile, body weight, nutrient digestibility and ovarian morphology.

\section{Abbreviations \\ ALA: a-Linolenic acid; CRD: Completely randomized design; DHA: Docosahex- aenoic acid; EPA: Eicosapentaenois acid; FSH: Follicle stimulating hormone; GnRH: Gonadotropin-releasing hormone; HDL: High density lipoprotein; IM: Intramuscular; LDL: Low density lipoprotein; LH: Luteinizing hormone; $\Omega$-3 PUFAs: Omega-3 polyunsaturated fatty acids; PCOS: Polycystic ovarian syndrome.}

\section{Acknowledgements}

The authors would like to acknowledge the Department of Physiology, Faculty of Life Sciences, Government College University, Faisalabad, Pakistan, for its 
support in biochemical analysis. The authors are also highly obliged to the Library Department, Government College University Faisalabad (GCUF) and IT Department, Higher Education Commission (HEC, Islamabad) for access to journals, books and valuable database.

\section{Authors' contributions}

FK and MUN developed the study protocol; FK carried out experiments; MKK and HA contributed to experimental measurements, discussion and interpretation of the results; MHA, NA, MI and UAA supported in data processing; FK and AM wrote the preliminary draft; RSA and MN helped out in interpretation of the results and related revisions. All authors read and approved the final manuscript.

\section{Funding}

The research was completed after utilizing the available resources in the Institute and University.

\section{Availability of data and materials}

The dataset supporting the conclusions of this article is included within the article.

\section{Ethics approval and consent to participate}

Animal Ethical Committee of Government College University, Faisalabad, Pakistan had proved this research by adopting Principles of Laboratory Animal Care.

\section{Consent for publication}

Not applicable.

\section{Competing interests}

The authors declare that they have no competing interests.

\begin{abstract}
Author details
${ }^{1}$ Institute of Home and Food Sciences, Faculty of Life Sciences, Government College University, Faisalabad, Punjab, Pakistan. ${ }^{2}$ Department of Physiology, Faculty of Life Sciences, Government College University, Faisalabad, Punjab, Pakistan. ${ }^{3}$ Department of Bioinformatics and Biotechnology, Faculty of Life Sciences, Government College University, Faisalabad, Punjab, Pakistan. ${ }^{4}$ Department of Dairy Technology, University of Veterinary and Animal Sciences, Lahore, Punjab, Pakistan.
\end{abstract}

Received: 4 May 2020 Accepted: 8 September 2020 Published online: 14 September 2020

\section{References}

1. Baptiste CG, Battista C, Trottier A, Baillargeon JP. Insulin and hyper-androgenism in women with polycystic ovary syndrome. J Steroid Biochem Mol Biol. 2012;122:42-52.

2. Ehrmann DA. Polycystic ovary syndrome. N Engl J Med. 2005;352:1223-366.

3. Möhlig M, Spranger J, Osterhoff M, Ristow M, Pfeiffer AF, Schill T, Schlösser HW, Brabant G, Schöfl C. The polycystic ovary syndrome per se is not associated with increased chronic inflammation. Eur J Endocrinol. 2004;150:525-32.

4. Dunaif A. Citation for the 2000 Monsanto Clinical Investigator Award Lecture of The Endocrine Society to Dr. William F Crowley Endocr Rev. 2000;21:449-50.

5. Cussons AJ, Watts GF, Mori TA, Stuckey BG. Omega-3 fatty acid supplementation decreases liver fat content in polycystic ovary syndrome: a randomized controlled trial employing proton magnetic resonance spectroscopy. J Clin Endocrinol Metab. 2009;94:3842-8.

6. Kasim-Karakas S. Omega-3 fish oils and insulin resistance. In: Wildman R, editor. Handbook of nutraceuticals and functional foods. 2nd ed. Boca Raton, FL: CRC Press; 2006. p. 155-164.

7. Oh R. Practical applications of fish oil ( $n-3$ fatty acids) in primary care. J Am Board Fam Med. 2005;18:18-36.

8. Komal F, Nisa MU, Khan MK, Ashfaq UA, Manzoor F, Masroor A, Nadeem M, Amir RM, Kausar R, Huda NU. Evaluation of the efficacy of different sources of omega-3 fatty acids in polycystic ovarian syndrome (PCOS) induced rats. Pak J Pharm Sci. 2019;32(4):1781-8.

9. National Research Council: Nutrient requirements of laboratory animals. Washington, DC: National Academy Press 4th rev; 1995.

10. Ghasemzadeh A, Farzadi L, Khaki A, Ahmadi SK. Effect of Allium cepa seeds ethanolic extract on experimental polycystic ovary syndrome (PCOS) apoptosis induced by estradiol-valerate. J Life Sci. 2013;10:170-5.

11. Byers SL, Wiles MV, Dunn SL, Taft RA. Mouse estrous cycle identification tool and images. PLoS ONE. 2012;7(4):e35538.

12. Karateke A, Dokuyucu R, Dogan H, Ozgur T, Tas ZA, Tutuk O, Agturk G, Tumer C. Investigation of therapeutic effects of erdosteine on polycystic ovary syndrome in a rat model. Med Princ Pract. 2018;27(6):515-22.

13. Asghar A, Majeed MN. Chemical characterization and fatty acid profile of different sesame verities in Pakistan. Am J Sci Ind Res. 2013;4(6):540-5.

14. Rybak A, Wierzbicka A, Socha P, Stolarczyk A, Cukrowska B, Obrycki L, Wawer Z, Janas R, Oralewska B, Szaflarska-Poplawska A, Iwanczak B, CyrtaJarocka E, Grzbowska-Chlebowczyk U, Cichy W, Cjaza-Bulsa G, Socha J. Atherosclerotic risk factors in children with celiac disease. Gastroenterol Res Pract. 2020;2020:6138243.

15. Nisa M, Sarwar M, Lee W, Lee H, Ki K, Ahn B, Kim H. Influence of corn steep liquor on feeding value of urea treated wheat straw in buffaloes fed at restricted diets. Asian-Australas J Anim Sci. 2006;19:1610-6.

16. Steel RG, Torries JH, Dickey DA. Principles and procedures of statistics A Biometerical. 3rd ed. New York: McGraw-Hill; 1997.

17. Tzang B, Yang S, Fu S, Yang H, Sun H, Chen Y. Effect of dietary flaxseed oil on cholesterol metabo- lism of Hamsters. Food Chem. 2009;1 14:1450-5.

18. Wiesenfeld PW, Babu US, Collins TFX, Sparndo R, Donell MWO, Flynn TJ, Black T, Olejnik N. Flaxseed increased a-linoleic acid and eicosapentaenoic acid and decreased arachidonic acid in serum and tissues of rat dams and offspring. Food Chem Toxicol. 2003;41:841-55.

19. Abdel MS. The effects of varieties sources of omega-3 fatty acids on diabetes in rats. Food Nutr Sci. 2012;3:1404-12.

20. Jump DB, Botolin D, Wang Y, Xu J, Christian B, Demeure O. Fatty acid regulation of hepatic gene transcription. J Nutr. 2005;135:2503-6.

21. Flachs P, Rossmeisl M, Bryhn M, Kopecky J. Cellular and molecular effects of n-3 polyunsaturated fatty acids on adipose tissue biology and metabolism. Clin Sci. 2009;116:1-16.

22. Gregory CS, Susan VP, Hansen N, Brandenburg V, Harris WS. Effects of prescription niacin and omega-3 fatty acids on lipids and vascular function in metabolic syndrome: a randomized controlled trial. J Lipid Res. 2012;53:2429-35.

23. Hultin M, Savonen R, Olivecrona T. Chylomicron metabolism in rats: lipolysis, recirculation of triglyceride-derived fatty acids in plasma FFA, and fate of core lipids as analyzed by compartmental modeling. J Lipid Res. 1996;37:1022-36.

24. Toth PP. High density lipoprotein cardiovascular risk. Circulation. 2009; 109:1809-1812.

25. Azadeh N, Razieh D, Hoorieh D, Mohammad HL, Niloofar V, Hassan MK. The effect of omega-3 supplementation on androgen profile and menstrual status in women with polycystic ovary syndrome: A randomized clinical trial. Iran J Reprod Med. 2013;11:665-72.

26. Demirel F, Bideci A, Cinaz P, Camurdan MO, Biberoglu G, Yesilkaya E, Hasanoğlu A. Serum leptin, oxidized low density lipoproteinand plasma asymmetric dimethylarginine levels and their relationship with dyslipidaemia in adolescent girls with polycystic ovary syndrome. Clin Endocrinol. 2007;67:129-34.

27. Phelan N, O'Connor A, Tun TK, Correia N, Boran G, Roche HM, Gibney J. Hormonal and metabolic effects of polyunsaturated fatty acids in young women with polycystic ovary syndrome: results from a crosssectional analysis and a randomized, placebo-controlled. Am J Clin Nutr. 2011;93:652-62.

28. Fatima FK, Abubacker SF, Ruckmani A, Vijayalakshmi K, Karunya LG, Ranjini S, Duraivel M. Effects of flaxseeds supplementation in polycystic ovarian syndrome. Int. J Pharm Sci Rev Res. 2015;31:113-19.

29. Nowak DA, Snyder DC, Brown AJ, Demark-Wahnefried W. The effect of flaxseed supplementation on hormonal levels associated with polycystic ovarian syndrome: a case study. Curr Top Nutraceutical Res. 2007;5:177-81.

30. Sturgeon SR, Heersink JL, Volpe SL, Bertone-Johnson ER, Puleo E, Stanczyk FZ, Sabelawski S, Wahala K, Kurzer MS, Bigelow C. Effect of dietary 
flaxseed on serum levels of estrogens and androgens in postmenopausal women. Nutr Cancer. 2008;60:612-18.

31. Zheng $S H, L i X L$. Visceral adiposity index as a predictor of clinical severity and therapeutic outcome of PCOS. Gynecol Endocrinol. 2016;32:177-83.

32. Mohammadi E, Rafraf M, Farzadi L, Asghari-Jafarabadi M, Sabour S. Effects of omega-3 fatty acids supplementation on serum adiponectin levels and some metabolic risk factors in women with polycystic ovary syndrome. Asia Pac J Clin Nutr. 2012;21:511-8.

33. Forouhia N, Bidarb SS, Djafarian K. Effect of omega-3 fatty acids supplementation on testosterone levels in women with polycystic ovary syndrome: Meta-analysis of randomized controlled trials. J Nutr Sci Diet. 2015;1:165-70.

34. Monk JM, Turk HF, Liddle DM, De Boer AA, Power KA, Ma DW, Robinson LE. N-3 polyunsaturated fatty acids and mechanisms to mitigate inflammatory paracrine signaling in obesity-associated breast cancer. Nutrients. 2014;6:4760-93

35. Sahar $\mathrm{S}$. The effects of varieties sources of omega-3 fatty acids on diabetes in rats. Food Nutr Sci. 2012;3:1404-12.

36. Shariati M, Mohammad MT, Hamid RJ. Effect of dietary fish oil and corn oil in blood biochemical factors in diabetic rats. Clin Biochem. 2011;44:133-40

37. Djousse L, Hunt SC, Tang W, Eckfelatt JH, Province MA, Ellison RC. Dietary linolienic acid and fasting glucose and insulin, the national heart, lung and blood institute family heart study. Obesity. 2006;14:295-300.

38. Elhabiby MI, Abo HK, Al-Dahody NZ, Shaikh AAR, El-Nabaheen EM, Hamad AR, Alsuhaibani SA, Hasan M, Mohieldein AH. Use of omega-3 supplements for the amelioration of glucose levels and lipid profile parameters in female university. Asian J Med Health. 2017;9:1-8.

39. Taghizadeh M, Jamilian M, Mazloomi M, Sanami M, Asemi Z. A randomized-controlled clinical trial investigating the effect of omega-3 fatty acids and vitamin $\mathrm{E}$ cosupplementation on markers of insulin metabolism and lipid profiles in gestational diabetes. J Clin Lipidol. 2016:10:386-93.

40. Bhaswant M, Poudyal H, Brown L. Mechanisms of enhanced insulin secretion and sensitivity with n-3 unsaturated fatty acids. J Nutr Biochem. 2015;26:571-84.

41. Shida T, Kamei N, Takeda-Morishita M, Isowa K, Takayama K. Colonic delivery of docosahexaenoic acid improves impaired glucose tolerance via GLP-1 secretion and suppresses pancreatic islet hyperplasia in diabetic KK-A(y) mice. Int J Pharm. 2013;450:63-9.

42. Han L, Shumin S, Yabing N, Meng M, Wang C. Eicosapentaenoic acid (EPA) induced macrophages activation through GPR120-mediated Raf-ERK1/2IKKß-NF-KB p65 signaling pathways. Nutrients. 2017;9:937.

43. Ravussin E. Adiponectin enhances insulin action by decreasing ectopic fat deposition. J Pharmacogenomics. 2002;2:4-7.

44. Lam T, Carpentier A, Lewis G, Werve G, Fantus IG. Mechanism of free fatty acid-induced increase in hepatic glucose production. Am J Physiol Endocrinol Metab. 2003;284:863-73.

45. Vaughan RA, Garcia-Smith R, Bisoffi M, Carole AC, Kristina AT. Conjugated linoleic acid or omega 3 fatty acids increase mitochondrial biosynthesis and metabolism in skeletal muscle cells. Lipids Health Dis. 2012;11:142.

46. Harden CJ, Jones AN, Maya-Jimenez T, Barker ME, Hepburn HJ, Garaiova I, Plummer SF, Corfe B. Effect of different long-chain fatty acids on cholecystokinin release in vitro and energy intake in free-living healthy males. British J Nutr. 2012;108:755-8.

47. Buckley J, Peter D, Howe RC. Long-chain omega-3 polyunsaturated fatty acids may be beneficial for reducing obesity-a review. Nutrients. 2010;2:1212-30.
48. Nuernberg K, Breier BH, Jayasinghe SN, Bergmann $\mathrm{H}$, Thompson N, Nuernberg G, Dannenberger D, Schneider F, Renne U, Langhammer M. Metabolic responses to high-fat diets rich in n-3 or $n-6$ long-chain polyunsaturated fatty acids in mice selected for either high body weight or leanness explain different health outcomes. Nutr Metab. 2011;8:56

49. Bathena SJ, Ali A, Haudenschild C, Latham P, Ranich T, Mohamed Al, Hansen CT, Velasquez MT. Dietary flaxseed meal is more protective than soy protein concentrate against hypertriglyceridemia and steatosis of the liver in an animal model of obesity. J Am Coll Nutr. 2003;22:157-64.

50. Bender K, Walsh S, Evans ACO, Fair T, Brennan L. Metabolite concentrations in follicular fluid may explain differences in fertility between heifers and lactating cows. Reprod. 2010;139:1047-55.

51. Senger PL. Pathways to pregnancy and parturition. Second revised edition. USA: Current Conceptions, 2005;187-341.

52. Watanabe K. Prostaglandin F synthase. Prostaglandins Other Lipid Mediat. 2002;68-69:401-7.

53. Zidkova J, Sajdok J, Kontrova K, Kotrbova-Kozak A, Hanis T, Zidek V, Fucikova A. Effects of oxidised dietary cod liver oil on the reproductive functions of Wistar rat. Czech J Food Sci. 2004;22:108-20.

54. Mossa F, Walsh SW, Butler ST, Berry DP, Carter F, Lonergan P, Smith GW, Ireland JJ, Evans AC. Low numbers of ovarian follicles $\geq 3 \mathrm{~mm}$ in diameter are associated with low fertility in dairy cows. J Dairy Sci. 2012;95:2355-61.

55. Mannerås L, Cajander S, Holmäng A, Seleskovic Z, Lystig T, Lönn $M$, Stener-Victorin E. A new rat model exhibiting both ovarian and metabolic characteristics of polycystic ovary syndrome. Endocrinology. 2007;148:3781-91.

56. Manni L, Cajander S, Lundeberg T, Naylor AS, Aloe L, et al. Effect of exercise on ovarian morphology and expression of nerve growth factor and alpha(1)- and beta(2)-adrenergic receptors in rats with steroid-induced polycystic ovaries. J Neuroendocrinol. 2005;17:846-58.

57. Benrick A, Maliqueo M, Miao S, Villanueva JA, Feng Y, Ohlsson C, Duleba AJ, Stener-Victorin E. Resveratrol is not as effective as physical exercise for improving reproductive and metabolic functions in rats with dihydrotestosterone-induced polycystic ovary syndrome. Evid Based Complement Alternat Med. 2013:96:4070.

58. Elaheh O, Arash K, Laya F, Zahra F, Behnam A. Effect of omega-3, fatty acids on ovarian tissue in polycystic ovarian (PCO) rats. Asian Pac J Trop Biomed. 2012;1-3.

59. Rizk AY, Bedaiwy MA, Al-Inany HG. N-acetyl-cysteine is a novel adjuvant to clomiphene citrate in clomiphene citrateresistant patients with polycystic ovary syndrome. Fertil Steril. 2005;83:367-70.

60. Smink W, Gerrits WJJ, Hovenier R, Geelen MJH, Lobee HWJ, Verstegen MWA, Beynen AC. Fatty acid digestion and deposition in broiler chickens fed diets containing either native or randomized palm oil. Poult Sci. 2008;87:506-13.

61. Wiseman J, Lessire M. Interactions between fats of differing chemical content: apparent metabolisable energy values and apparent fat digestibility. Br Poult Sci. 1987;28:663-76.

\section{Publisher's Note}

Springer Nature remains neutral with regard to jurisdictional claims in published maps and institutional affiliations.

Ready to submit your research? Choose BMC and benefit from:

- fast, convenient online submission

- thorough peer review by experienced researchers in your field

- rapid publication on acceptance

- support for research data, including large and complex data types

- gold Open Access which fosters wider collaboration and increased citations

- maximum visibility for your research: over $100 \mathrm{M}$ website views per year

At BMC, research is always in progress.

Learn more biomedcentral.com/submissions 